\title{
Interaction of Monetary and Macro-prudential Policies: The Case of Jordan- Credit Gap as an Example
}

\author{
Rami Obeid ${ }^{1} \nless$ \\ Bassam Awad ${ }^{2}$
}

${ }^{1}$ Head of Data Analysis \& Management Division, Central Bank of Jordan, Amman, Jordan

Email:rami.obeid3@gmail.com Tel:962-795-855-036

'Head of Systemic Risk \& Macro-prudential Policy Analysis Division, Central Bank of Jordan, Amman, Jordan

Email:bra05@my.su.edu Tel:962 795-088-481

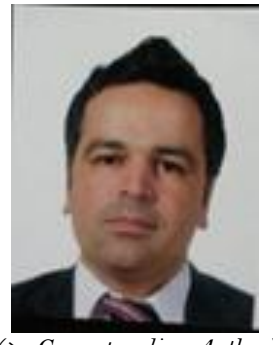

Corresponding Author)

\begin{abstract}
This study aims at investigating the extent of interaction between monetary policy and macroprudential policy in Jordan during the period (2005-2015) using the Vector Error Correction Model (VECM) to check the presence of short-term and long-term impacts of the monetary policy tools in general on the accumulation of systemic risks in the banking system. Systemic risk was measured using the credit gap. The results showed the existence of a statistically significant negative effect of deposit window rate and required reserve ratio on the accumulation of systemic risks, whereas the rediscount rate had a positive effect.
\end{abstract}

Keywords: Macro-prudential policy, monetary policy, countercyclical capital buffer, Credit gap

JEL Classification: E44; E52; E58; E61; G18.

Citation | Rami Obeid; Bassam Awad (2018). Interaction of Monetary and Macro-prudential Policies: The Case of JordanCredit Gap as an Example. Asian Journal of Economics and Empirical Research, 5(1): 99-111.

History:

Received: 18 July 2018

Revised: 13 August 2018

Accepted: 15 August 2018

Published: 18 August 2018

Licensed: This work is licensed under a Creative Commons

Attribution 3.0 License (cc) BY

Publisher:Asian Online Journal Publishing Group
Contribution/Acknowledgement: All authors contributed to the conception and design of the study.

Funding: This study received no specific financial support.

Competing Interests: The authors declare that they have no conflict of interests.

Transparency: The authors confirm that the manuscript is an honest, accurate, and transparent account of the study was reported; that no vital features of the study have been omitted; and that any discrepancies from the study as planned have been explained.

Ethical: This study follows all ethical practices during writing.

\section{Contents}

1. Introduction

2. Research Problem

100

3. Research Questions

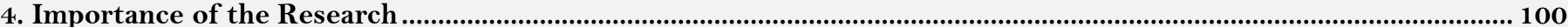

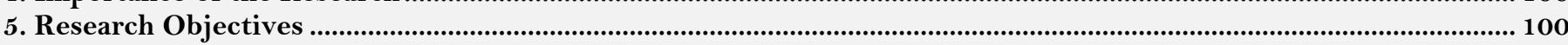

6. Research Hypothesis ...........100

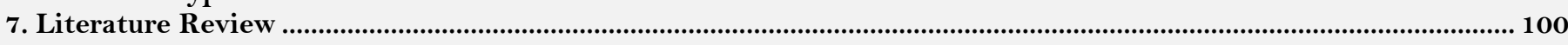

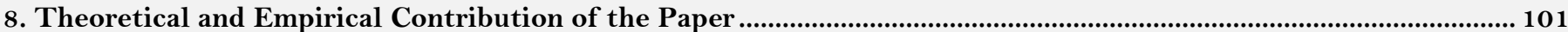

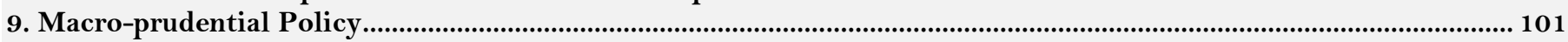

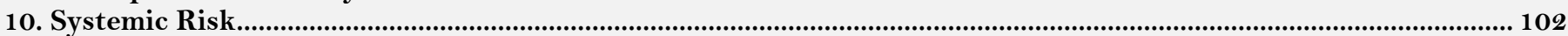

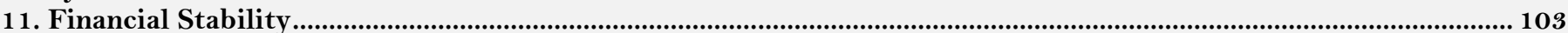

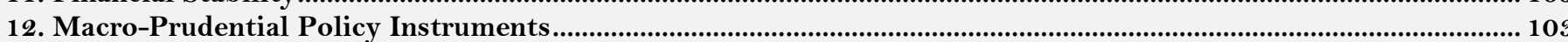

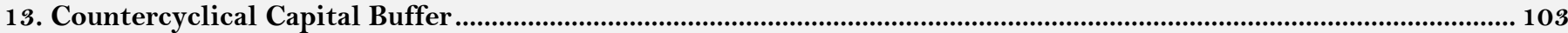

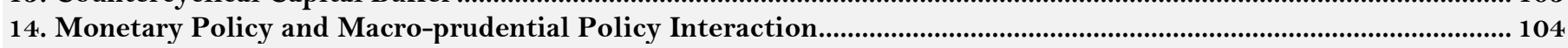

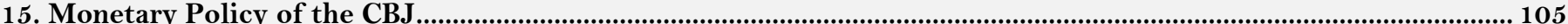

16. The Ratio of Credit Granted by Banks to the Private Sector to GDP ..................................................................... 106

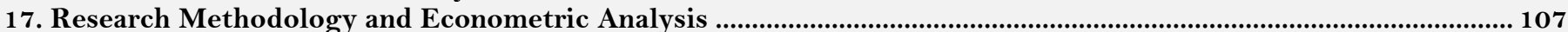

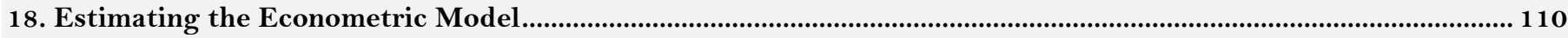

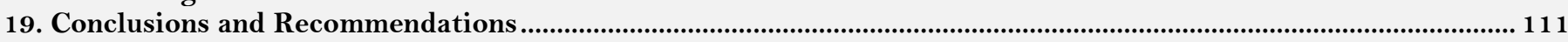

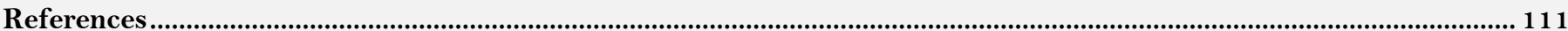




\section{Introduction}

The last global financial crisis revealed the need for linking financial risks with economic risks through the socalled macro-prudential policy ${ }^{1}$. This policy aims at maintaining financial stability as an ultimate goal through identifying, monitoring and quantifying the systemic risks in the financial system as a whole (Claessens et al., 2013). Several studies, like Claessens et al. (2013) stressed the necessity of coordinating monetary and macroprudential policies so that their objectives do not conflict. The interest of monetary authorities in the world in maintaining financial stability significantly increased after the conclusion of the global financial crisis through the newly emerged macro-prudential policy that was included to the duties of the monetary authorities in many world countries. The regulatory monetary authorities paid extra attention to the risks of the excessive credit expansion as it might lead to the accumulation of systemic risks. For example, the growth of household debt at higher rates than their income or net wealth might signal increases in credit risk for this sector, which in turn might adversely affect financial and economic stability. This entails on the banking sector to monitor the risks associated with the lending offered to the household sector. The expansion of credit to this sector must take into consideration these risks. The monetary authorities were made aware to the importance of continually monitoring and assessing systemic risks after the global financial crisis through the implementation of macro-prudential policy tools that alleviate the risks that the financial sector as a whole might be subjected to, and that enhance its capacity to withstand shocks.

\section{Research Problem}

This study inspects the extent of the interaction between monetary policy and macro-prudential policy in Jordan by examining the effect of the adjustments in monetary policy instruments on the accumulation of systemic risks in the banking system in Jordan through realizing that adjusting monetary policy instruments do not lead to an Increase in the credit gap, ${ }^{2}$ and, hence the accumulation of systemic risks in the banking system during the study period.

\section{Research Questions}

The study tries to answer the following two questions:

1. Has the use of monetary policy instruments led to the accumulation of systemic risk in the banking system during the study period?

2. Do adjustments in monetary policy instruments lead to widening the credit gap in Jordan?

\section{Importance of the Research}

The importance of investigating the interaction of monetary policy with macro-prudential policy is due to the high interconnection between the two policies. If the monetary authority cut the interest rates on monetary policy instruments, the banks might react by cutting the interest rates imposed on credit facilities. This might consequently reduce the net interest margin in the banking system. In turn, this encourages the households to demand more borrowing and hence their indebtedness goes up excessively leading to accumulation of systemic risks possibly. The cut of the monetary policy interest rates might lead to increase in the value of assets fueled by the increasing demand on real estate loans that are offered at relatively lower costs (interest rates). The exaggerated real estate prices might create a financial crisis in case these prices decrease sharply by forces like economic downturns (Beyer et al., 2017).

\section{Research Objectives}

This paper aims at conforming to the regulatory authorities represented by the central banks the importance of coordination between monetary policy and macro-prudential policy changes in the monetary policy instruments interest rates might cause accumulation of systemic risks arising from excessive credit growth that is disproportionate to the growth in the real economy (GDP growth). This consequently might adversely affect the stability of both the financial system and the economic system.

\section{Research Hypothesis}

The paper examines the following hypothesis:

There is no effect of monetary policy instruments on the accumulation of systemic risks (the widening of credit gap) at $10.0 \%$ level of significance.

\section{Literature Review}

There are several studies in the literature that researched the interaction between monetary policy and macroprudential policy. In general, the path of the investigation was through examining the effect of monetary policy on the accumulation of systemic risks. For example, Goodhart et al. (2009) and Illing (2006) found that the tight monetary policy might lead to an increase in default rates of borrowers from the banks, a decrease in bank's profitability rates and an increase in non-performing loans that collectively might cause an accumulation of systemic risk that might eventually cause a financial crisis (Goodhart et al., 2009); (Illing, 2006).

Dell'Ariccia et al. (2010); Borio and Zhu (2012) and Valencia (2014) inserted that the expansionary monetary policies might motivate banks to increase their risk appetite. In turn, they are encouraged to extend more credit at

1. The macro-prudential policy is defined as the policy under which systemic risk is identified, monitored and controlled to mitigate the accumulation of these risks and enhance the ability of the financial system to withstand shocks using a set of tools based on key indicators (Central Bank of Jordan, 2012).

${ }^{2}$ The quarterly credit gap is calculated by dividing the amount of loans at the end of a given quarter by the annualized GDP - the value of GDP in the relevant quarter plus the GDP in the previous three quarters. The difference between this value (called actual credit to GDP ratio) and its long-term trend (extracted using The Hodrick-Prescott filter) is the credit gap 
low interest rates. This might also be accompanied by insuficient assessment of their cleints' solvency before extending the credit. As a result, the systemic risk increases (Dell'Ariccia et al., 2010); (Borio and Zhu, 2012); (Valencia, 2014).

Claessens et al. (2013) indicated that cutting interest rates on monetary policy instruments will make the banks cut their interest rates on the credit extended to their clients. Consequently, the total size of credit facilities increases, leading to increase in asset prices and, hence, the accumulation of systemic risks (Claessens $\mathrm{et} \mathrm{al.,} 2013$ ).

As for the credit gap determinants, the studies are small in this regard. This is mostly attributed to the fact that the credit gap concept came to attention after the recent global financial crisis. In this regard, the Basel Committee on Banking Supervision (BCBS) issued a guide in 2010 that includes an algorithm for calculating credit gap (Basel Committee on Banking Supervision, 2010).

Gersl and Seidler (2012) surveyed the determinants of credit gap (as conceptualized by BCBS). They found that household consumption and per capita GDP both had a statistically significant positive effect on credit gap in the long run at $1.0 \%$ level of significance as the credit gap in the long-term rises with the rise in household's wealth and the increase in their consumption (Gersl and Seidler, 2012). Similarly, the household consumption in the short run had a statistically significant positive effect on the credit gap at $5.0 \%$ level of significance. In contrast, inflation had a statistically significant negative effect on the gap at $10.0 \%$ level of significance. In light of the results of the econometric analysis, the study concluded that inflation and interest rates on monetary policy instruments are negatively related with credit gap. The decline in both the interest rates on monetary policy instruments and inflation rates result in lower interest rates on bank lending and, hence, higher demand for credit by households, leading eventually to widening in the credit gap (Gersl and Seidler, 2012).

\section{Theoretical and Empirical Contribution of the Paper}

It is inevitable the importance of coordinating macro-prudential policy and monetary policy, especially since both policies, as it is mostly the case, are formulated by the monetary authority. The Central Bank of Jordan is an example, the paper targets to enhance the capacity of CBJ in evaluating the effect of monetary policy on credit gap in Jordan, besides stressing the vital role of macro-prudential policy in curbing the buildup of systemic risk and the importance of policy coordination in general. And in particular, when credit grows excessively and disproportionately with the growth in the real economy leading to the accumulation of systemic risks and might create imbalances in the financial system and the economy as a whole.

\section{Macro-prudential Policy}

There is a high degree of uncertainty when it comes to the concept of macro-prudential policy and its role in maintaining financial and monetary stability. This uncertainty includes its objectives, tools and management and implementation. There are varied opinions when it comes to the role of macro-prudential policy. For example, does the policy aim at protecting the banking and financial systems from the fluctuations in the economic cycle? If so, then the policy objective is maintaining financial stability. Alternatively, does the macro-prudential policy aim at protecting the economy from the fluctuations in the financial cycle? If this is the case, then the macro-prudential policy is more oriented towards the macro-economy (Akerlof et al., 2014). Moreover, despite the presence of new supervisory authorities that are responsible for formulating and implementing the macro-prudential policy in both advanced and emerging economies, there are some ambiguities regarding the role of the policy, how to implement it and when it can be more effective (Aikman et al., 2013).

Prior to the global financial crisis, there were no linkages (i.e. coordination) between the major economic policies (monetary and fiscal policies) and the micro-prudential policy (financial supervision). Put differently, economic risks and financial risks were independent. Economic policymaking does not take into consideration the financial risks that might emerge through the implementation of the policies, aiming solely at achieving price stability and maintaining sustainable economic growth. Similarly, the micro-prudential policy (financial supervision) does not count for economic risks, targeting to achieve its own objective of maintaining the soundness of financial institutions on individual level only, but not collectively, therefore, the risk that the financial system as a whole might be vulnerable to and affected adversely by, the systemic risk, was not taken into consideration (Figure 1).

One of the lessons from the global financial crisis is that maintaining financial stability on the individual level of the institutions in the financial system is insufficient to maintain the stability of the financial system as the whole.

How we saw the world before the financial crisis

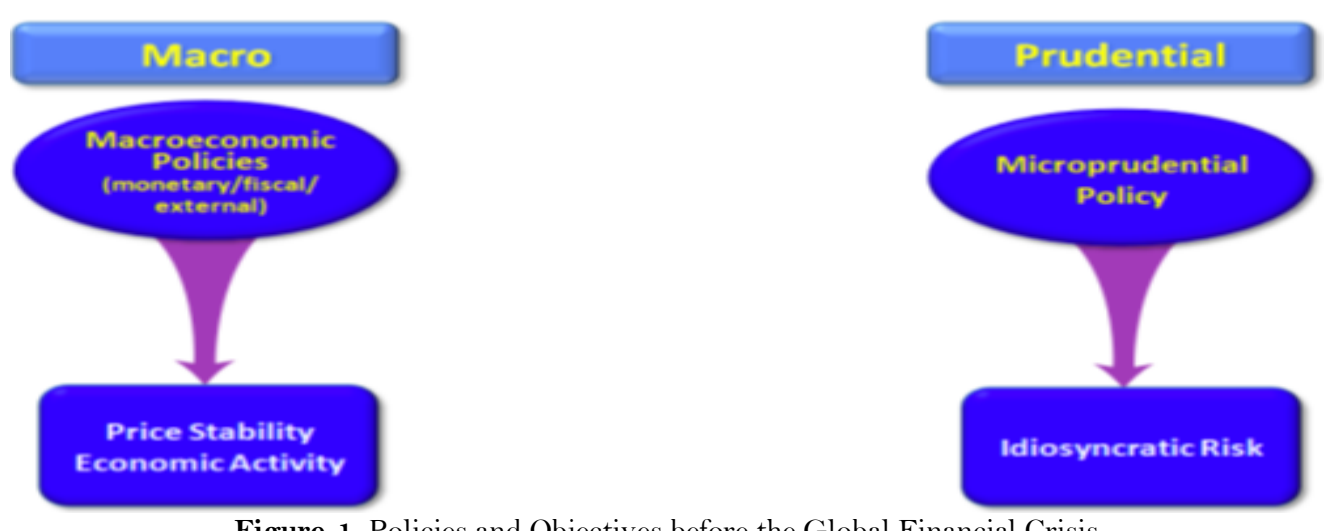

Figure-1. Policies and Objectives before the Global Financial Crisis

Source: International Monetary Fund. 
During the crisis, the financial positions of many financial institutions in the United States of America were relatively stable, but the bankruptcy of Lehman Brothers Bank was followed by the collapse of other banks affected by the contagion risk. The crisis exacerbated further spread cross border from USA to hit the world so that the entire global financial system has been put to the test, which has adversely impacted the economies of countries outputting heavy losses for many years. In sum, the stability of both financial and economic systems can only be achieved if financial and economic risks are both taken into consideration when making economic and macroprudential policies decision.

As a result of the global financial crisis, the supervisory authorities became aware of the vital importance of coordinating economic policies and micro prudential policies through the so-called macro-prudential policy that targets achieving and maintaining financial stability on the entire financial system's level. This macro-prudential policy interlinks economic and financial risks to achieve its main objective (Figure 2) through identifying, monitoring and controlling systemic risks using several tools that consider matching the developments in the financial system with the developments in the real economy. The macro-prudential policy curbs the ability of the financial system in extending credit through the activation of the appropriate macro-prudential instrument that is compatible with the stance of the economy. For example, during boost, the real estate prices might follow a fast and positive trend (put simply, real estate bubble) and can be therefore used as collaterals for loans, leading to increased demand for credit by individuals and households. During recessions, however, the situation is reversed, the real estate prices decrease sharply, leading to a decline in the value of the credit extended. The economic situation worsens even more as a result of the decline in the value of real estate asset as collateral for the credit extended and decline in the ability of households to repay their obligations. Consequently, the bank sells the mortgages at lower prices than the value of the credit extended (as was with the global financial crisis).

The macro-prudential policy mainly targets to control and supervise the ability of banks in extending excessive credit using the suitable instrument - during boost periods. Thereby helps protect financial stability and economy from severe losses.

\section{How we see the world now}

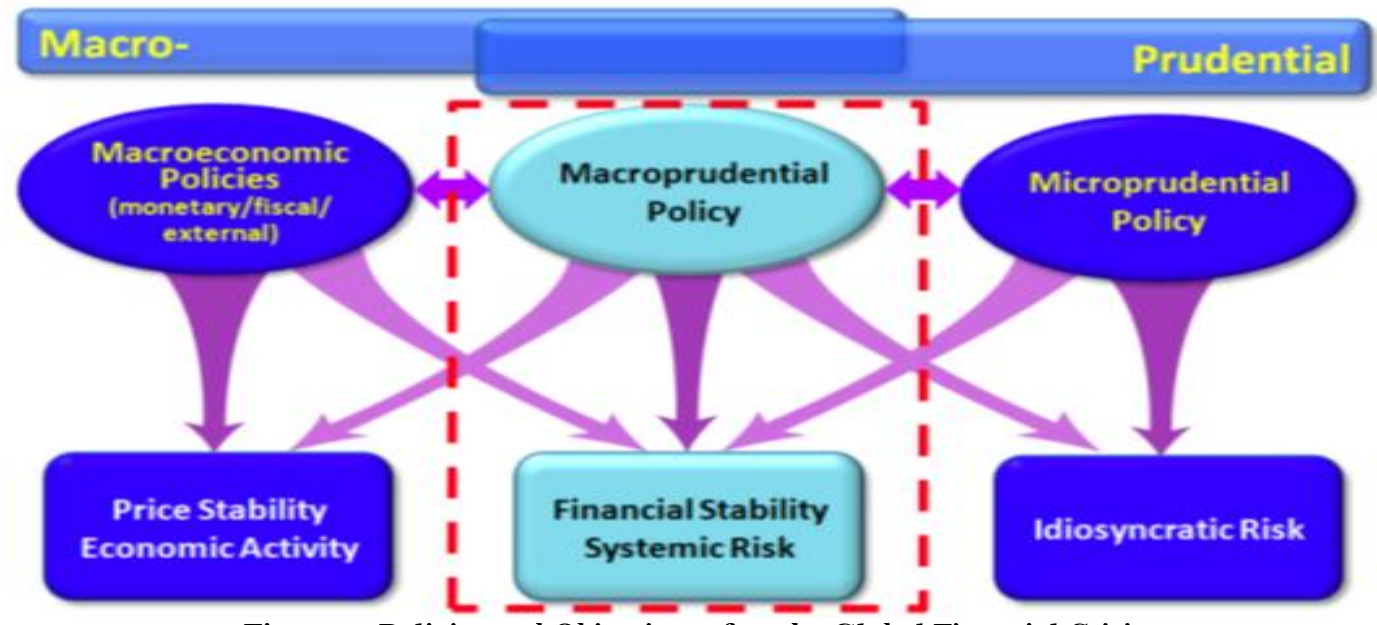

Figure-2. Policies and Objectives after the Global Financial Crisis

Source: International Monetary Fund.

The comparison of policies and objectives before and after the global financial crisis as shown in Figure 1 and Figure 2 respectively clearly shows the important role of Macro-prudential policy. Before the emergence of this policy, the micro-prudential policy was the actor in achieving its major goal of maintaining financial stability on the individual institutional level regardless of the economic policies in general and monetary policy in particular. Similarly, the monetary policy directed toward achieving price stability and promoting economic activity regardless of the performance or stance of the micro-prudential policy.

In the wake of the global financial crisis, decision makers in the regulatory authorities have alerted to the importance of balancing economic policies and micro-prudential policies so that these policies are linked. Thus, the macro-prudential policy was developed to act as a link between micro-prudential policy and the economic policies. The objective of the macro-prudential policy is to achieve financial stability as an ultimate policy objective by using of some tools that take account of the prevailing conditions in both the financial and economic systems. In addition, the macro-prudential policy promotes the ability of financial and banking sectors to withstand economic and financial shocks that they may face at any time. Under any circumstances, the macro-prudential policy needs support from the other economic policies in order to achieve its objectives. In this regard, the monetary policy must be conducted effectively (Borio, 2012).

\section{Systemic Risk}

One of the most important lessons that are learned from the global financial crisis that financial stability at the micro level of the banking system is insufficient to achieve financial stability at the macro level because of the socalled systemic risks that hit the whole financial system. The 2012 Financial Stability Report published by the CBJ defined systemic risks as the risks that affect the entire financial system (CBJ, 2012). Examples of systemic risks are:

Excessive credit growth that does not match the size of economic activity, in such a case, the credit is directed towards the nonproductive consumption sectors. For example, the banks' expansion of credit to the household sector might result in a slowdown in economic growth as a result of the increase in imports that negatively affects trade balance. 
1. High exposure to assets (stocks and real estate) that witness a large increase, which might consequently lead to price bubbles.

2. High exposure of banks to the mostly nonproductive household sector at the expense of the productive corporate sector.

Bernanke defined systemic risk as "developments that threaten the stability of the financial system as a whole and consequently the broader economy, not just that of one or two institutions" (CBJ, 2012).

Bank for International Settlements, the International Monetary Fund and the Financial Stability Board agreed on defining on defining systemic risk as "the risk of widespread disruption to the provision of financial services that is caused by an impairment of all or parts of the financial system, and which can cause serious negative consequences for the real economy" (FSB/IMF/BIS, 2009). In other words, systemic risks are costs or financial losses caused by that disruption reflected in either the financial sector or the real economy or both in case of occurrence of financial crisis. Relying on the previous discussion, it can be concluded that systemic risk arises by the interaction of three forces: a financial shock, an interruption in the provision of financial services and the materialization of economic losses.

\section{Financial Stability}

Economists have put several definitions for financial stability. However, these definitions are similar in context despite different wordings. For example, Laker (1999) indicated that in light of the fact that achieving financial stability is itself an objective, then "the objective of financial system stability could therefore be defined, in broad terms, as the avoidance of disruptions to the financial system that are likely to cause significant costs to real output" (Laker, 1999); (Alawode and Al Sadek, 2008). According to Schinasi (2004) "financial stability is defined in terms of its ability to facilitate and enhance economic processes, manage risks, and absorb shocks. Moreover, financial stability is considered a continuum: changeable over time ..." (Schinasi, 2004). He also pointed out that the financial system will stable if it promotes the performance of the economy and overcomes the financial imbalances arising from unexpected adverse events. In other words, financial stability is the case where the economic mechanisms of pricing and financial risk management (credit risk, liquidity risk, market risk, operating risk. etc.) are working in such a way as to contribute to the performance of the economy.

In line with the previous discussion, it can be clearly concluded that the definition of financial stability is linked to the components and activities of the financial system. Besides, the role of the monetary authority in achieving or maintaining financial stability is vital due to the fact that the monetary authority is usually the leader supervisory party on the banking and financial institutions.

Financial Stability was defined by the CBJ in its JFSR 2012 as the situation under which the financial system (that includes financial intermediaries like banks, markets stocks; derivatives and bonds, and market infrastructure like payment systems) is capable of withstanding shocks and adjusting imbalances without interrupting the financial intermediation process through facilitating the smooth flow of funds between savers and investors and, by doing so, help promote growth in economic activity (CBJ, 2012).

\section{Macro-Prudential Policy Instruments}

The macro-prudential supervision is defined as the supervision of financial institutions and their transactions on a macro level. Therefore, the micro supervision on individual institutions is not part of the macro-prudential supervision mandate. The macro-prudential policy is defined as the policy under which systemic risk is identified, monitored and controlled to mitigate the accumulation of these risks and enhance the ability of the financial system to withstand shocks using a set of tools based on key indicators. The macro-prudential policy gained a special focus after the 2008 global financial crisis.

Based on the classification set by the Committee on the Global Financial System with the BIS, the macroprudential policy instruments are classified into three main categories, capital-based instruments, liquidity-based instruments and asset-side instruments.

Capital-based instruments include countercyclical capital buffers, sectorial capital requirements, and dynamic provisions; whereas liquidity-based instruments encompass net stable funding ratio and liquidity coverage ratio. Asset-side instruments are loan-to-value ratio (LTV) and debt-to-income (DTI) ratio.

There is another classification of the macro-prudential policy instruments set by the IMF. It divided the instruments into two main groups. One group is designed to mitigate systemic risk like the asset-side based tools. The other group of tools is designed to enhance the resilience of the financial system to withstand shocks like capital-based and liquidity-based tools.

There are two determinants of the activation of deactivation of the macro-prudential policy instruments:

1. The appropriate timing for activating or deactivating the macro-prudential policy instruments.

2. The appropriate macro-prudential policy instrument(s).

The financial cycle is considered a very important factor in determining the appropriate timing for operationalizing the macro-prudential policy instruments. ${ }^{3}$ At the boom stage of the financial cycle, the macroprudential policy instruments must be activated to curb the appetite of banks in offering credit to protect the economic and financial system from bearing severe losses in case dangers materialize. At the bust stage, the monetary policy instruments must be released to motivate the banks to provide credit to motivate the economy.

\section{Countercyclical Capital Buffer}

The proportionality of the growth of the credit granted to the private sector with the size of economic activity is one of the driving forces that ensure that credit is directed towards the productive economic sectors. This proportionality is abbreviated by the ratio of private credit to GDP. The importance of this ratio is that it measures

${ }^{3}$ Financial cycle characterizes the behaviour of the credit-to-GDP ratio, quantity of credit, assets prices (real estate and stocks). Akerlof, Blanchard, Romer and Stigliz (2014). 
systemic risks from a financial and economic perspective by examining the degree of harmony of two important macro indicators: (1) the credit granted to the private sector by banks and other financial institutions and (2) GDP.

The BCBS released a guide to the relevant supervisory authorities entitled "Guidance for National Authorities Operating the Countercyclical Capital Buffer" (BCBS, 2010). The guidance details an algorithm for determining the amount of the countercyclical capital buffer that banks and financial institutions needed to maintain the proportionality of financial and real sectors trends.

1. Collecting historical quarterly data of credit extended to the private sector by banks and other financial institutions and GDP.

2. Calculating the credit-to-GDP ratio in period $t$.

3. Estimating the trend of the ratio of private credit-to-GDP in period $t$ using econometric software. ${ }^{4}$

4. Calculating the credit-to-GDP gap. The credit-to-GDP ratio is compared to its long-term trend. If the credit-to-GDP ratio is significantly above its trend (i.e., there is a large positive gap), then this is an indication that credit may have grown excessively relative to GDP growth. In mathematical terminology, Gap $=$ (credit/GDP*100\%)-Trend. If this gap is greater than $10.0 \%$, then the authorized entity mandates the banks to add a buffer to its capital equal to $2.5 \%$ of Risk-Weighted Assets (RWA). Moreover, if this gap is less than $2.0 \%$, then the authorized entity does not mandate banks to make any additions. Finally, If this gap ranges between these two limits $(2.0 \%-10.0 \%)$, then the authorized entity mandates the banks to add a buffer to its capital equal that ranges between $0.0 \%$ and $2.5 \%$ of Risk-Weighted Assets (RWA) based on the formula: $C C B=2.5 \% / 8.0 \% \times(G a p-2.0 \%)$.

\section{Monetary Policy and Macro-prudential Policy Interaction}

The coordination of macro-prudential and monetary policies is elements that must be considered when formulating a framework for macro-prudential policy since both policies aimed at achieving financial stability and affecting real economic variables.

Both macro-prudential policy and monetary policy to influence the price and quantity of credit in the economy, which in turn is likely to affect overall economic activity, the contradiction could take place with the implementation of these two policies. For example, using one or more monetary policy instruments targeting to cut down interest rates leads to an increase in the amount of credit in the economy. At the same time, the macroprudential policy while keeps an eye on credit growth might use some instruments to curb the growth of credit above desired limits (long-term trends) through the activation of one more macro-prudential policy instruments. Similarly, real economic activity and interest rates influence systemic risk via their impact on the size of credit that is considered one of the most important factors that lead to the accumulation of systemic risk in the financial sector.

Moreover, both monetary and macro-prudential policymakers build their decisions in practice using similar data, pointing to potential interactions. For example, financial conditions such as lending conditions and credit size are important information sources for monetary policy and would of course constitute core inputs to macroprudential policymaking. On the other hand, the macro-prudential policymaker would also take the state of the business cycle and the stance of monetary policy into account in deciding the appropriate macro-prudential instruments.

The paper of Claessens et al. (2013) about "Interaction of Monetary and Macro-prudential Policies" stressed the importance of monetary and macro-prudential policies' coordination even though the task cannot be easily performed. The policy coordination will most likely have positive effects on enhancing financial stability since monetary policy helps in maintaining the balance in the economy, and the macro-prudential policy aims at addressing the imbalances in the financial system. The absence of coordination between the two policies might a failure of each of them in achieving its objective.

The previous reveals the importance of both policies being managed by the monetary authorities. The existence of a single institutional framework reduces the possibility of conflicting independent policy decisions. Price stability - the ultimate goal of monetary policy - does not guarantee economic stability in the absence of effective treatment of macro-financial risks that are within the tasks of macro-prudential policy.

Empirical evidence has shown that the instability in the financial system undermines the stability of the economy even if the inflation rate is maintained stable and low. The macro-prudential policy instruments are complementary to monetary policy instruments in countering the cyclical fluctuations of the economy. In this regard, some instruments of the macro-prudential policy (e.g., capital adequacy and loan-to-value (LTV) ratio) that do not only achieve the macro-prudential policy objectives, but also the objectives of monetary policy (Federico et al., 2014); (Tovar et al., 2012). Therefore, policymakers paid more attention to the relationship between the two policies. As previously stated, monetary policy is primarily aimed at maintaining price stability; while the macroprudential policy is primarily aimed at maintaining financial stability.

The relationship between monetary policy and macro-prudential policy is counterbalanced by the "side effects" resulting from each one of another. These interactions could enhance or downgrade the effectiveness of each policy in achieving its objectives (Gerlach et al., 2009). For example, monetary policy instruments might encourage banks to expand credit in a period when the macro-prudential policy is aimed at controlling the leverage ratio. The activation of one of the macro-prudential policy instruments to reduce credit granted by banks to the private sector might lead to a contradiction in case of adopting an expansionary monetary policy aiming at promoting economic growth.

In the existence of coordination between the two policies, they are supportive of each other. For example, the absence of reaction of economic variables to a deflationary monetary policy can be resolved by imposing a ceiling on the LTV ratio instrument of macro-prudential policy and thus controlling the banks' capacity to grant excessive credit (Igan and Kang, 2011). Similarly, the absence of reaction of economic variables to an expansionary monetary policy can be resolved by cutting down on the limit of LTV ratio as an instrument of macro-prudential policy and thus enhancing the banks' capacity to grant more credit. Any increase in banking risk arising from the

${ }^{4}$ One of the most commonly used software in this kind of research is E-Views that can be used to estimate trend using The Hodrick-Prescott (HP) filter 
expansionary monetary policy and the reduction of the LTV ratio can be controlled by raising capital requirements, liquidity or leverage.

\section{Monetary Policy of the CBJ}

The CBJ continued to implement monetary policy to achieve monetary and financial stability in the Kingdom, by continuing to follow economic conditions and various relevant variables and then using all the tools available at the appropriate time for achieving those goals. These tools are divided into main interest rates and open market operations. Within the context of the CBJ's strategy of continuous development of its monetary policy tools to achieve its objectives in line with the economic and monetary conditions, it has established an operational framework of monetary policy and its tools to determine their effectiveness in achieving the objectives of monetary policy. Because of the aforementioned revision, since 2012, the CBJ continuously review and update the monetary policy operational framework and its tools. The most recent update granted the commercial banks and the CBJ more flexibility in managing liquidity in line with financial and monetary conditions under the high volume of financing needs for Jordan.

\subsection{Updating the Monetary Policy Operational Framework \\ 15.1.1. Temporary Open Market Operations}

These operations are designed to enhance open-market operations to influence the size of the excess reserves and adjusting overnight interbank rates within the Corridor System and targeting market interest rates at the desired level of monetary policy, by introducing the securities repurchase agreements for a week to a month through auctions conducted by the CBJ.

\subsubsection{Outright Open Market Operations}

This tool provided the CBJ of the ability to access the money market as a seller and buyer of Government securities and guaranteed pump or withdrawal liquidity in accordance with the requirements of economic activity, and to enhance the role of the secondary market dealing in bonds.

\subsubsection{Currency Swap}

According to this tool, the CBJ made several foreign currency swaps in Jordanian dinars in response to requests by licensed banks to strengthen the dinar liquidity of banks.

\subsubsection{Corridor System}

Where this system is used in the implementation of monetary policy, it aims at adjusting to influence the overnight interbank interest rate, which in turn affects interest rates in the market. The overnight deposit interest rate represents the floor of the system while the repurchase agreement interest rate represents the ceiling of the system. The REPOs are initiated by banks in case they needed liquidity with no limits for one night only. The interest rate on the overnight REPOs is the upper limit in the corridor system. Whereas the overnight deposit window transactions are initiated by banks as well but their interest rates are the lower limit of the corridor system. Figure 3 shows the trends of the overnight deposit window rate, the overnight REPOs rate (and the corresponding corridor system) and the overnight interbank loan rate, as might be realized from the figure that the overnight interbank interest rate moving between the overnight deposit interest rate and the REPOs rate.

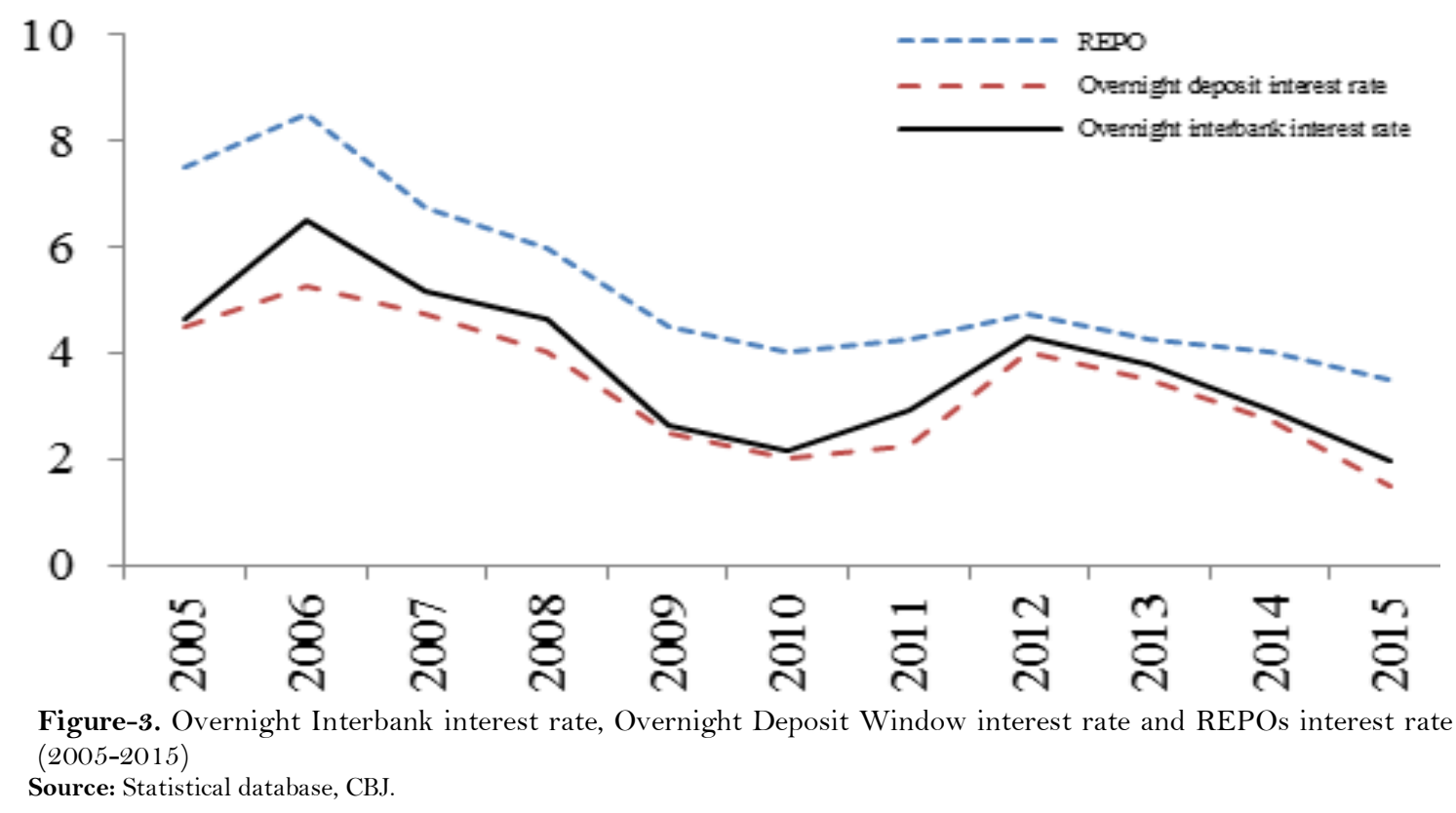

\subsubsection{CBJ Main Rate}

At the beginning of 2015 , CBJ adopted this price as a main interest rate for managing the monetary policy. The CBJ main rate was decided to range between $2.5 \%$ and $2.75 \%$ (expressed in terms of REPOs for one week). This action aims to give clear signals about the stance of monetary policy and orientation about the domestic and international economic monetary and economic conditions. 


\subsubsection{Certificates of Deposit (CDs)}

To develop liquidity management tools to enhance the ability of banks to manage their liquidity efficiently and effectively, the CBJ issued certificates of deposit with specific maturities and values in 2015 for the first time since 2008. This aims to attract part of the liquidity of banks through auctions within the range of pricing determined by the $\mathrm{CBJ}$ in accordance with the terms of this tool.

\subsection{Traditional Monetary Policy Instruments}

Regarding the traditional monetary policy instruments, the CBJ have manipulated these instruments several times in the past few years in the light of the conditions, developments, and challenges the Jordanian economy faces as reflected on the trends in major macroeconomic variables like the stock of foreign reserves, current account deficit and inflation rates. Other drivers for the policy instruments changes included enhancing a growthenhancing environment and availing of credit at reasonable costs for financing various economic activities. Table 1 summarizes the main developments in rediscount rate and interest rates on overnight repurchase agreements and overnight deposit window, besides overnight interbank lending interest rate ${ }^{5}$ and required reserve ratio on bank deposits.

Table-1. Monetary Policy Instruments Rates (2005-2015) (\%)

\begin{tabular}{|c|c|c|c|c|c|}
\hline Year & $\begin{array}{l}\text { Rediscount } \\
\text { Rate }\end{array}$ & $\begin{array}{l}\text { Overnight } \\
\text { Repurchase } \\
\text { Agreements Rate }\end{array}$ & $\begin{array}{l}\text { Overnight Deposit } \\
\text { Window Rate }\end{array}$ & $\begin{array}{l}\text { Weighted Average } \\
\text { of } \quad \text { Interbank } \\
\text { Overnight Lending } \\
\text { Rate } \\
\end{array}$ & $\begin{array}{lr}\text { Required Reserve } \\
\text { Ratio on Bank } \\
\text { Deposits }\end{array}$ \\
\hline 2005 & 6.50 & 7.50 & 4.50 & 4.63 & 8.00 \\
\hline 2006 & 7.50 & 8.50 & 5.25 & 6.50 & 8.00 \\
\hline 2007 & 7.00 & 6.75 & 4.75 & 5.15 & 8.00 \\
\hline 2008 & 6.25 & 6.00 & 4.00 & 4.65 & 9.00 \\
\hline 2009 & 4.75 & 4.50 & 2.50 & 2.65 & 7.00 \\
\hline 2010 & 4.25 & 4.00 & 2.00 & 2.15 & 7.00 \\
\hline 2011 & 4.50 & 4.25 & 2.25 & 2.92 & 7.00 \\
\hline 2012 & 5.00 & 4.75 & 4.00 & 4.31 & 7.00 \\
\hline 2013 & 4.50 & 4.25 & 3.50 & 3.79 & 7.00 \\
\hline 2014 & 4.25 & 4.00 & 2.75 & 2.94 & 7.00 \\
\hline 2015 & 3.75 & 3.50 & 1.50 & 1.96 & 7.00 \\
\hline
\end{tabular}

\subsection{Macro-prudential Policy at the Central Bank of Jordan}

The 2008 global financial crisis highlighted the importance of maintaining financial stability. The discussion of monetary and fiscal policies is no longer separated from policies related to policies targeting to control systemic risk. Therefore, there is a vital need to focus on developing instruments for managing macro-prudential policy at central banks that consider the objective of maintaining financial stability on the macro level (Arab Monetary Fund, 2017).

\section{The Ratio of Credit Granted by Banks to the Private Sector to GDP}

The ratio of credit provided by the financial institutions to the private sector to GDP is a very important ratio that measures the consistency of the credit granted to the private sector with the pace of economic activity. In other words, this ratio can be visualized as an assessment of directing funding to the productive sector rather than concentrated in the consumption sectors and/or real estate and assets sector. The excessive lending to the later sectors might lead to jumps in asset prices and creating price bubbles that adversely affect economic and financial stability. The importance of this ratio was highlighted after the 2008 global financial crisis. Economists in general and monetary authorities in specific were criticized for not linking economic indicators with financial indicators when building their projections about the risks of economic and financial crises in the future. The importance of this ratio is that it measures systemic risk from both economic and financial prospects through monitoring and analyzing the harmony and consistency of two important indicators: the credit granted by banks and other financial institutions to the private sector and the gross domestic product. The ratio is compared to its long-term trend. The difference between the two variables is called credit gap. Systemic risks increase as the larger the difference of the ratio from its long-term trend (CBJ, 2012).

Per Basel III guidelines, the banks must maintain a countercyclical capital buffer to counteract any possible adverse consequences of the fluctuations in economic and financial cycles. The buffer ranges between 0 and $2.5 \%$ of the risk-weighted assets of common-equity capital (CET1) that is applied gradually on a span of four years, given that minimum stable funding is available to banks, besides some minimum liquidity levels that enhance the capacity of banks in meeting their obligations toward their customers.

The result of the analysis of the credit gap in Jordan revealed that the gap was below $2.0 \%$. It reached about $1.1 \%$ at the end of 2015. Therefore, the countercyclical capital buffer tool of macro-prudential policy does need to be activated. Therefore, the growth of credit granted to the private sector by the financial institutions is consistent with the growth in the real economy - the GDP.

It worth mentioning that the gap exceeded 2.0\% just before the 2008 global financial crisis, it ranged between $4.1 \%$ and $8.4 \%$ during the period (Q4:2006-Q3:2008). This means that during that period, there was a vital need for activating the countercyclical capital buffer tool of macro-prudential policy (assuming that it the tool was available during this period). This gives an important lesson that systemic risks can be clearly evaluated using the analysis of the credit gap. Figure 4 depicts the actual credit-to-GDP ratio, its trend and credit gap for the period (2005-2015).

${ }^{5}$ The overnight interbank lending interest rate is not a monetary policy instrument but included in the discussion for its importance as being targeted and managed indirectly by monetary policy instruments. 


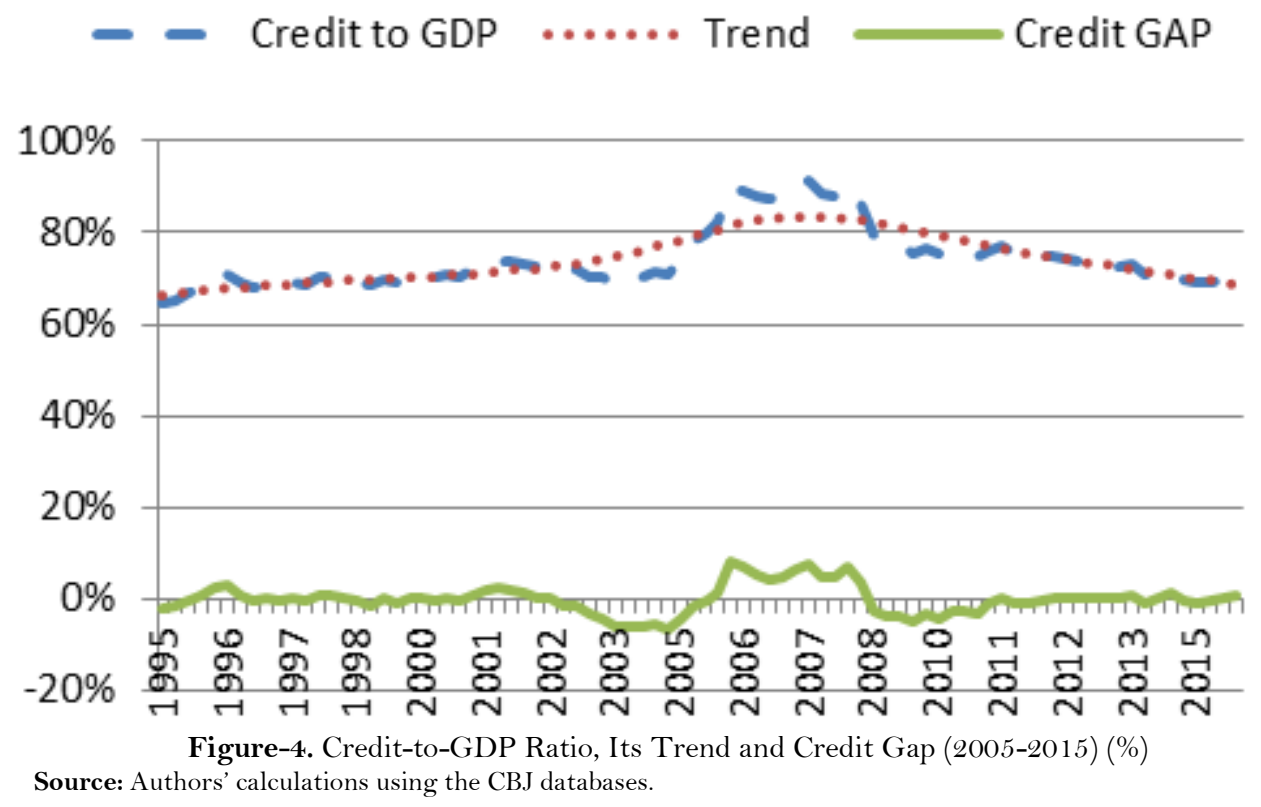

\section{Research Methodology and Econometric Analysis \\ 17.1. Data Sources and Sample}

Regarding the effect of monetary policy instruments on the credit gap for all the commercial banks working in Jordan during the study period (19 banks), the study relied on the quarterly data obtained from the CBJ's database published on its website.

\subsection{The Model Used for Measuring the Effect of Monetary Policy Instruments on Systemic Risk Accumulation in the Banking System}

Regarding the model used to estimate the effect of monetary policy instruments on the accumulation of systemic risk in the banking system in Jordan, it was as follows:

\section{Where}

$$
g_{t}=\beta_{0}+\beta_{1} r_{t}+\beta_{2} w+\beta_{3} d_{t}+\epsilon_{t}
$$

g: credit gap. It is the deviation of the actual ratio of credit granted by the commercial banks to the private sector to GDP from its long-term trend estimated using the Hodrick-Prescott (HP) filter.

r: required reserve ratio. Which is a percentage imposed on banks' deposits and held at the monetary authority - usually the central bank without getting any interest returns. The goal of this ratio is providing the minimum liquidity requested by any commercial bank. The high this ratio, the lower the excess liquidity available at banks (if any) and, hence, the lower the credit available for granting loans. In contrast, the lower the required reserve ratio, the higher the excess liquidity at banks and the higher the amounts available for extending credit facilities.

w: overnight deposit window rate. Which is the rate paid on excess liquidity of banks, the commercial bank deposit this liquidity in the CBJ for one night. The higher the interest rate paid by the CBJ on the overnight deposit window, the more willing are banks to deposit their excess liquidity at the CBJ instead of offering more loans to their clients, conversely, the lower the rate, the less willing and more reluctant the banks to deposit their excess liquidity using this window at the CBJ. Consequently, the excess liquidity is offered to the bank clients, it worth mentioning that the overnight deposit window rate mirrors the attractiveness of the Jordanian Dinar.

d: the discount rate. Also called rediscount rate, or bank rate, interest rate charged by the CBJ for loans of reserve funds to commercial banks and other financial intermediaries. The banks may approach this path in order to obtain more funds for granting credit facilities. The higher the rate, the more reluctant banks to ask for loans, the lower the liquidity.

The nature of the relationship between these independent variables and credit gap depends on their effect on credit (the numerator of the credit-to-GDP ratio) and GDP (the denominator of the credit-to-GDP ratio). For example, if the relationship between any of the independent variables in the previous equation (required reserve ratio, overnight deposit window rate and discount rate) and the credit gap is negative. This is attributed to the fact that cutting these rates increased credit more that the GDP. Therefore, the lower these rates, the higher the liquidity levels at banks. Consequently, they will offer more credit and hence possibly systemic risks might build up. Put differently, both interest rates and economic activity affect systemic risk through their effect on asset prices and leverage at the bank (CBJ, 2012).

\subsection{Econometric Analysis before Estimation}

\subsubsection{Correlations}

The strength of the relationship among study independent variables are used to examine the presence of the problem of multicollinearity. This problem is considered severe in case the correlation coefficient between two independent variables exceeds 0.80 (Obeid and Adeinat, 2017).

Table 2 shows the correlation matrix for the model's variables, which are required reserve ratio, overnight deposit window rate and the discount rate. As appear from the table, all correlations in the matrix are accepted and less than 0.7. Therefore, there is no need for testing multicollinearity using the VIF test. 
Table-2. Model's Correlation Matrix

\begin{tabular}{l|l|l|l}
\hline & $\mathbf{r}$ & $\mathbf{w}$ & $\mathbf{D}$ \\
\hline $\mathrm{R}$ & 1.0000 & 0.6203 & 0.6943 \\
\hline $\mathrm{W}$ & 0.6203 & 1.0000 & 0.6262 \\
\hline $\mathrm{D}$ & 0.6943 & 0.6262 & 1.0000 \\
\hline \multicolumn{2}{l}{ Source: Authors' calculations }
\end{tabular}

\subsection{Stationary Test}

Before analyzing the results of the econometric model, the stationarity of time series must be tested to examine the presence of unit root problem in any of the model variables. ADF and PP test were conducted to test for stationarity and degree of cointegration. As many time series are non-stationary because of the presence of unit root in its structure. The unit root in time series means that the mean and the variance of the variable are not time invariant. The assumption of stationarity in time series that includes unit root in econometric models leads misleading statistical results - the so-called spurious regression. The analysis and econometric inference as well will be misleading and defective despite the high value of the coefficient of determination $\left(\mathrm{R}^{2}\right)$ and t-statistic. ADF and PP tests are the most commonly used tools for testing the stationarity of a time series and the determination of its degree of cointegration.

Table 3 shows the results of the two tests. As appears from the table, the independent variables of the model were level non-stationary but attained stationarity at taking the first difference, indicating a degree of cointegration of I(1). Similarly, the dependent variable was level; nonstationary in the estimations that included no intercept and/or trend for both ADF and PP tests.

Table-3. Stationarity Testing Using ADF \& PP Tests for the Study Variables

\begin{tabular}{|c|c|c|c|c|c|c|}
\hline \multirow[t]{2}{*}{ Level } & \multirow[b]{2}{*}{$\mathbf{C}$} & \multirow[b]{2}{*}{$\mathrm{C}+\mathrm{T}$} & \multirow[b]{2}{*}{ None } & \multicolumn{3}{|c|}{ First-differences } \\
\hline & & & & C & $\mathrm{C}+\mathrm{T}$ & None \\
\hline & ADF & & & & & \\
\hline $\bar{G}$ & -2.1602 & -2.563 & $-2.0498^{* *} *$ & $-5.6363 * * *$ & $-5.0630 * * *$ & $-5.7059^{*} * *$ \\
\hline $\mathrm{R}$ & -2.2431 & -3.0848 & -0.5274 & $-7.9554^{* * * *}$ & $-7.8556 * * *$ & $-8.0267 * * *$ \\
\hline $\mathrm{W}$ & -0.4721 & -3.1054 & -0.6399 & $-4.2642^{* * * *}$ & $-4.3858^{* * * *}$ & -4.2835 **** \\
\hline \multirow[t]{2}{*}{$\mathrm{d}$} & -0.6559 & -3.1374 & -0.364 & $-3.5679^{* *}$ & $-3.6891 * *$ & $-3.6025^{* * *}$ \\
\hline & $\mathrm{PP}$ & & & & & \\
\hline $\mathrm{g}$ & -2.35 & -2.6629 & $-2.2448^{* *}$ & $-5.6004 * * *$ & $-5.4984 * * *$ & $-5.6798 * * *$ \\
\hline $\mathrm{r}$ & -2.13 & -3.0816 & -1.1373 & $-10.188^{* * * *}$ & $-10.024 * * *$ & $-9.6433^{* * *}$ \\
\hline $\mathrm{W}$ & -1.2639 & -2.4733 & -0.7148 & $-4.3662 * * *$ & $-4.5880 * * *$ & $-4.4055 * * *$ \\
\hline $\mathrm{d}$ & -1.347 & -3.1873 & -0.428 & $-3.4734 * *$ & $-3.6947 * *$ & -3.5221 *** \\
\hline
\end{tabular}

C: Constant, T: Trend

\subsection{Cointegration Testing}

Following the results of the stationarity testing for the model variables that indicated a first-difference stationarity, the test for cointegration of the model variables must be conducted. In case the test showed the presence of cointegration, the long-term relationship can be predicted. The most common method used for testing cointegration is Johansen method. According to this test, the null hypothesis for the trace test is that the number of cointegration vectors is less than or equal $\mathrm{r}$. The test helps determine the coefficient of the speed of adjustment. Johansen method includes two tests: Trace and Maximum Eigenvalue. Table 4 lists the results of tests. As appears from the table, Trace test shows that there exist at least three long-term relationships among the variables, whereas the Maximum Eigenvalue test shows that there exist at least two long-term relationships among the variables. Consequently, the VECM can be used.

Table-4. Cointegration of Model Variables Using Trace and Maximum Eigenvalue Methods

\begin{tabular}{|c|c|c|c|c|}
\hline \multicolumn{5}{|c|}{ Unrestricted Cointegration Rank Test (Trace) } \\
\hline Null Hypothesis & Eigenvalue & Trace Statistic & $5 \%$ Critical Value & Prob. \\
\hline None * & 0.6660 & 82.3496 & 47.8561 & 0.0000 \\
\hline At least $1 *$ & 0.4555 & 39.5819 & 29.7971 & 0.0027 \\
\hline At least $2 *$ & 0.2703 & 15.8761 & 15.4947 & 0.0438 \\
\hline At least 3 & 0.0878 & 3.5845 & 3.8415 & 0.0583 \\
\hline \multicolumn{5}{|c|}{ Unrestricted Cointegration Rank Test (Maximum Eigenvalue) } \\
\hline \multirow[t]{2}{*}{ Null Hypothesis } & Eigenvalue & Max-Eigen & $5 \%$ Critical Value & Prob. \\
\hline & & Statistic & & \\
\hline None * & 0.6660 & 42.7678 & 27.5843 & 0.0003 \\
\hline At least $1 *$ & 0.4555 & 23.7057 & 21.1316 & 0.0212 \\
\hline At least 2 & 0.2703 & 12.2917 & 14.2646 & 0.1002 \\
\hline At least 3 & 0.0878 & 3.5845 & 3.8415 & 0.0583 \\
\hline
\end{tabular}

Based on the results of stationarity and cointegration tests, the paper uses the Vector Error Correction Model (VECM) to measure the impact of monetary policy instruments on credit gap in Jordan. This test link between short-term and long-term changes for the variables used in the study during the adjustment process, until reaching the long-term balance. This model can be applied for small samples according to Greene (2007) cointegration relationship is required (by Johansen method) before applying this model. Error correction method requires data that have the same degree of integration at level and differences in the same equation, the deviations from a longrun equilibrium are corrected gradually by the dynamics and partial adjustments in the short terms. In light of the results of the cointegration test, the long-term relationship can be checked using VECM. 
Regarding the calculation of the optimal number of lags (Lag Length Selection), Table 5 shows that the optimal number of lags for both models and using both AIC and HQC is seven. However, when using the VECM model, one lag will be eliminated, maintaining six lags for the model. It is worth mentioning that the selection of optimal lag periods depends on the frequency of the used data. The number of lag periods is usually small for the annual data, and it gets bigger the more the data frequency.

Table-5. Results of Optimal Lag Length Selection Using Akaike Information

\begin{tabular}{l|l|l}
\multicolumn{4}{l}{ Criterion (AIC) and Hannan-Quinn Criterion (HQC) } \\
\hline Lag & AIC & HQ \\
\hline 0 & -26.50 & -26.44 \\
\hline 1 & -32.70 & -32.39 \\
\hline 2 & -32.10 & -31.55 \\
\hline 3 & -32.25 & -31.45 \\
\hline 5 & -32.36 & -31.31 \\
\hline 6 & -32.82 & -31.54 \\
\hline 7 & -33.25 & -31.72 \\
\hline Source: Authors' calculations & -35.38 & -33.60
\end{tabular}

\subsection{Stability Test}

In order to investigate the existence of any structural changes in the model variables (or, alternatively, the presence of structural stability), this paper examined the stability of the long-term parameters together with the short-term movements for the model utilizing the cumulative sum (CUSUM) and cumulative sum squares (CUSUMSQ) tests proposed by Borensztein et al. (1998). These tests show any structural change in the data, in addition to clarifying stability and harmony between the long term and short-term parameters (Borensztein et al., 1998). The existence of structural stability for the estimated parameters can be verified using graphical representation. If the plot of both tests CUSUM and CUSUMSQ stay within the critical $5 \%$ level bounds, there is structural stability in the model.

From Figure 5 and Figure 6 it can be realized that both plot of CUSUM and CUSUMSQ stay within the critical bounds, thus we can confirm the long-term relationships among model variables at 5.0\% level of significance, implying that there exists a harmony and stability in the model for the short-term and long-term results.

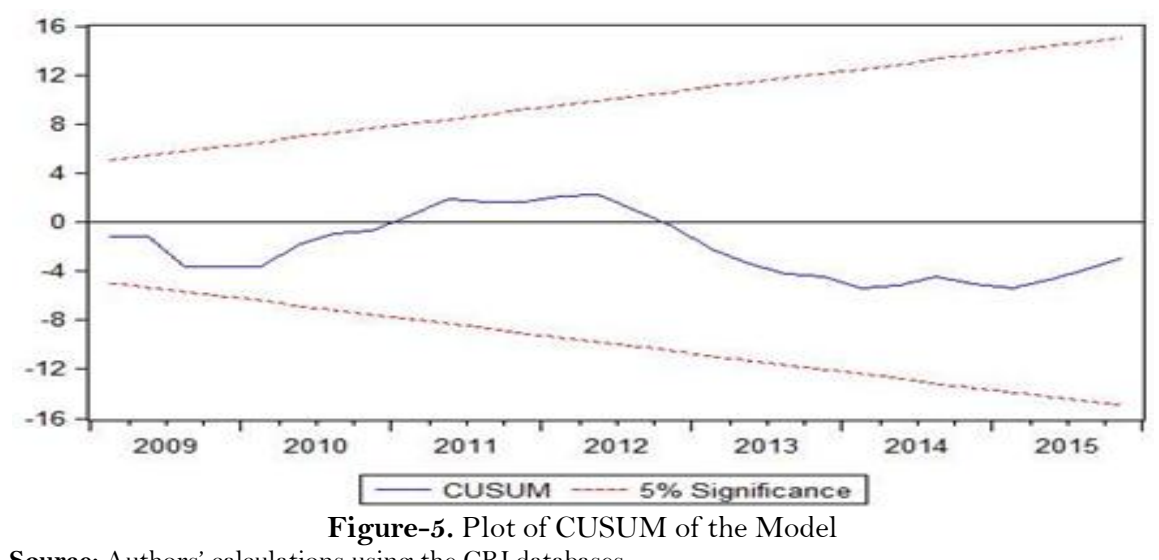

Source: Authors' calculations using the CBJ databases.

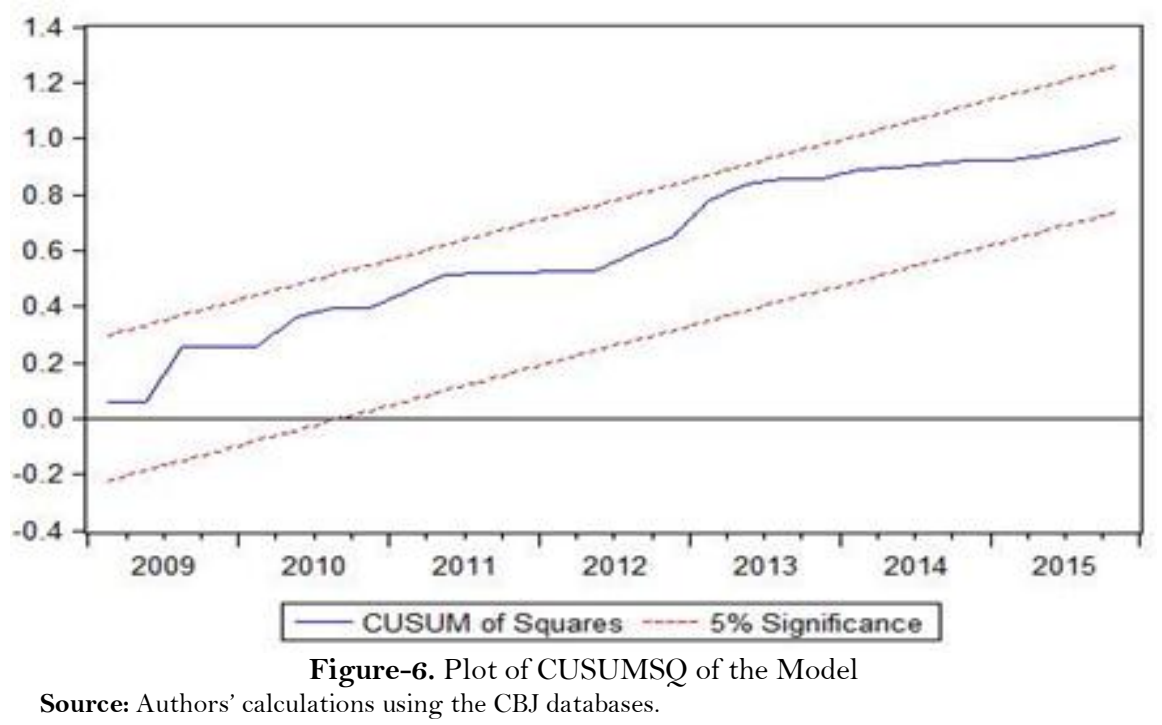

\subsection{Diagnostic Testing}

Table 6 shows the results of the diagnostic testing of the study model. The tests included Heteroscedasticity (is present when the size of the error term differs across values of an independent variable), Autocorrelation (the error terms are correlated with one another) using LM test, and Normality of distribution using Jarque-Bera test. The table shows that the probability of the three tests is well above $5.0 \%$ implying that the model does not suffer from any of these distortions that impact the validity of analysis. 
Table-6. Diagnostic Testing of the VECM Model

\begin{tabular}{l|ll}
\hline \multicolumn{3}{c}{ Table-6. Diagnostic Testing of the VECM Model } \\
\hline \multirow{2}{*}{ Residual Heteroscedasticity Test } & Chi-Square & 389.5853 \\
\cline { 2 - 3 } & Prob. & 0.2321 \\
\hline \multirow{2}{*}{ Residual Autocorrelation LM Test } & LM-Stat. & 13.28028 \\
\cline { 2 - 3 } & Prob. & 0.6522 \\
\hline \multirow{2}{*}{ Residual Normality Test } & Jarque - Bera & 0.27297 \\
\cline { 2 - 3 } & Prob. & 0.8724 \\
\hline \multirow{2}{*}{ Source: Authors' }
\end{tabular}

\section{Estimating the Econometric Model}

The results of the standard model estimation (Table 7 ) show that there are two monetary policy instruments that have a negative effect on the credit gap in the model. They are the required reserve ratio and the overnight deposit window interest rate. The effect of the discount rate on the credit gap was positive. In detail, the results showed that there is a statistically significant negative effect of the required reserve ratio on credit gap at $1.0 \%$ level of significance, which clearly indicates that the reduction of the required reserve ratio by the CBJ lead to the injection of liquidity into banks that in turn utilize it to extend more credit to their clients leading to accumulation of systemic risk in case the credit did not target the productive sectors. Allocating more credit to consumption sectors (households) rather than to productive sectors (companies) may lead to a discrepancy between credit growth and GDP growth and, hence, widening the credit gap. The gap may widen further if consumption credit facilities lead to increase in imports, which in turn may increase the deficit in the trade balance, resulting in a slowdown in economic growth.

As for the interest rate on the overnight deposit window, the negative effect of this variable on the credit gap was significant $1.0 \%$. Cutting the interest rate on the overnight deposit window by the CBJ reduce the banks' desirability to deposit their surplus liquidity with the CBJ. Instead, they will seek other ways to utilize their surplus liquidity at higher returns. Therefore, banks will increase the amount of credit extended, which will lead consequently to the accumulation of systemic risk and, hence, increase the credit gap in the same mechanism indicated previously about the effect of the required reserve ratio. Finally, the effect of the discount rate on the credit gap was a significantly positive at $1.0 \%$. The reduction of the discount rate by the CBJ led to an increase in the credit but at a rate less than the increase in GDP, which resulted in a decrease in the credit gap. Conversely, If the CBJ raises the discount rate, this will decrease credit at lower rates than the decrease in GDP and hence widen the credit gap.

Using the results in Table 7, the VECM model can be formulated to include long-term and short-term elasticity in addition to the error correction coefficient as follows:

$$
\begin{gathered}
D(g)=-0.45 \times\left[g_{-1}-2.66 d_{-1}+4.24 w_{-1}+5.62 r_{-1}-0.41\right] \\
D(g)=-0.45 g_{-1}+1.20 d_{-1}-1.91 w_{-1}-2.53 r_{-1}+0.18
\end{gathered}
$$

As shown in Table 7, the error correction coefficient is statistically significant, which implies that this term helps explain the changes in the credit gap. It indicates that about $45.0 \%$ of the deviations of the credit gap from its long-term trend are corrected during a period not greater than three quarters.

\begin{tabular}{|c|c|c|c|}
\hline \multicolumn{4}{|l|}{ Long-Term } \\
\hline Variable & Coefficient & Standard Error & t-Statistics \\
\hline $\mathrm{d}(-1)$ & -2.6575 & 0.8216 & -3.2345 \\
\hline $\mathrm{w}(-1)$ & 4.2426 & 0.5722 & 7.4147 \\
\hline$r(-1)$ & 5.6175 & 1.2327 & 4.5570 \\
\hline \multicolumn{4}{|l|}{ Short-Term } \\
\hline CoinEq1 & 0.4514 & 0.1967 & 2.2947 \\
\hline $\mathrm{D}(\mathrm{g}(-1))$ & 0.6640 & 0.4475 & 1.4837 \\
\hline $\mathrm{D}(\mathrm{g}(-2))$ & 0.8133 & 0.4453 & 1.8266 \\
\hline $\mathrm{D}(\mathrm{g}(-3))$ & 0.1300 & 0.2939 & 0.4424 \\
\hline $\mathrm{D}(\mathrm{g}(-4))$ & -0.0315 & 0.3524 & -0.0895 \\
\hline $\mathrm{D}(\mathrm{g}(-5))$ & -0.1324 & 0.2401 & -0.5514 \\
\hline $\mathrm{D}(\mathrm{g}(-6))$ & -0.3096 & 0.2648 & -1.1694 \\
\hline $\mathrm{D}(\mathrm{d}(-1))$ & 1.3539 & 2.7609 & 0.4904 \\
\hline $\mathrm{D}(\mathrm{d}(-2))$ & 2.0489 & 2.2091 & 0.9275 \\
\hline $\mathrm{D}(\mathrm{d}(-3))$ & 2.8283 & 2.5793 & 1.0965 \\
\hline $\mathrm{D}(\mathrm{d}(-4))$ & 0.5564 & 2.0371 & 0.2731 \\
\hline $\mathrm{D}(\mathrm{d}(-5))$ & 0.2538 & 1.9016 & 0.1335 \\
\hline $\mathrm{D}(\mathrm{d}(-6))$ & -0.1465 & 1.7128 & -0.0855 \\
\hline $\mathrm{D}(\mathrm{w}(-1))$ & -1.3687 & 1.5749 & -0.8691 \\
\hline $\mathrm{D}(\mathrm{w}(-2))$ & -1.6557 & 1.3864 & -1.1942 \\
\hline $\mathrm{D}(\mathrm{w}(-3))$ & -1.1623 & 1.6544 & -0.7026 \\
\hline $\mathrm{D}(\mathrm{w}(-4))$ & -1.7004 & 1.7874 & -0.9514 \\
\hline $\mathrm{D}(\mathrm{w}(-5))$ & 1.2195 & 1.6365 & 0.7452 \\
\hline $\mathrm{D}(\mathrm{w}(-6))$ & -1.0555 & 1.8318 & -0.5762 \\
\hline $\mathrm{D}(\mathrm{r}(-1))$ & 0.7585 & 1.3887 & 0.5462 \\
\hline $\mathrm{D}(\mathrm{r}(-2))$ & 0.3579 & 1.0341 & 0.3462 \\
\hline $\mathrm{D}(\mathrm{r}(-3))$ & 0.0291 & 0.9272 & 0.0314 \\
\hline $\mathrm{D}(\mathrm{r}(-4))$ & 2.1994 & 0.8368 & 2.6282 \\
\hline $\mathrm{D}(\mathrm{r}(-5))$ & 0.2762 & 0.9147 & 0.3019 \\
\hline $\mathrm{D}(\mathrm{r}(-6))$ & 0.2122 & 1.0380 & 0.2044 \\
\hline $\mathrm{C}$ & -0.0068 & 0.0039 & -1.7137 \\
\hline
\end{tabular}

Table-7. VECM Model Estimation 
The estimation results of the model revealed that there exists an inverse short-term and long-term relationship required reserve ratio and credit gap. The elasticity of the long-term relationship roughed 2.53 , meaning that a $10.0 \%$ decline in the required reserve ratio, for example, leads to an increase in the credit gap by $25.3 \%$, ceteris paribus. For the overnight deposit window, the results showed a negative effect on the credit gap, both in long and short terms. The elasticity of the long-term relationship roughed 1.91 , meaning that a $10.0 \%$ decline in the overnight deposit window rate leads to an increase in the credit gap by $19.1 \%$, ceteris paribus. Finally, regarding the discount rate, the results showed a positive effect of the rate on the credit gap, both in long and short terms. The elasticity of the long-term relationship roughed 1.20 , meaning that a $10.0 \%$ decline in the overnight deposit window rate leads to an increase in the credit gap by $12.0 \%$, ceteris paribus.

\section{Conclusions and Recommendations}

\subsection{Conclusions}

This study investigated the interaction between monetary policy and macro-prudential policy using the Vector Error Correction Model to test the existence of an impact (short-term or long-term) of monetary policy instruments in general, and the overnight deposit window in particular, on the accumulation of systemic risk in the banking sector. The systemic risk was measured by credit gap as detailed in the main text. The results showed that there exists a statistically significant negative effect of both the required reserve ratio and overnight deposit window and a statistically significant positive effect of discount rate on the dependent variable credit gap.

\subsection{Recommendations}

1- The Central Bank of Jordan should manipulate the monetary policy instruments prudently so that it takes into consideration their direct and indirect effect on the net interest margin and credit.

2- The CBJ should coordinate monetary policy and macro-prudential policy in order to clearly characterize the systemic risks and assess their impact on both economic and financial systemic. In particular, the impact of any monetary policy instrument must be clearly projected before manipulating that instrument.

\section{References}

Aikman, D., A.G. Haldane and S. Kapadia, 2013. Operationalising a macroprudential regime: Goals, tools and open issues. Bank of Spain Financial Stability Review, 24: 9-30. View at Google Scholar

Akerlof, G., O. Blanchard, D. Romer and J. Stigliz, 2014. What have we learned? Macroeconomic policy after the crisis. Cambridge, Mass. and London: MIT Press.

Alawode, A. and M. Al Sadek, 2008. What is financial stability. Financial Stability Paper Series, 1. Retrieved from http://www.cbb.gov.bh/assets/2008/What\%20is\%20Financial\%20Stability.pdf.

Arab Monetary Fund, 2017. Consensus of macroeconomic policies and policies, Working Paper No. 81/2017.

Basel Committee on Banking Supervision, 2010. Guidance for national authorities operating the countercyclical capital buffer, Bank for International Settlements.

Beyer, A., G. Nicoletti, N. Papadopoulou, P. Papsdorf, G. Rünstler, C. Schwarz and O. Vergote, 2017. The transmission channels of monetary, macro-and microprudential policies and their interrelations (No. 191). ECB Occasional Paper.

Borensztein, E., J. De Gregorio and J.W. Lee, 1998. How does foreign direct investment affect economic growth? Journal of International Economics, 45(1): 115-135. View at Google Scholar $\mid$ View at Publisher

Borio, C., 2012. The financial cycle and macroeconomics: What have we learned? BIS Working Papers.

Borio, C. and H. Zhu, 2012. Capital regulation, risk-taking and monetary policy: A missing link in the transmission mechanism? Journal of Financial Stability, 8(4): 236-251. View at Google Scholar

Central Bank of Jordan, 2012. Financial Stability Report.

Claessens, S., K. Habermeier, E. Nier, H. Kang, T. Mancini-Griffoli and F. Valenci, 2013. The interaction of monetary and macrorpudential policies. IMF Policy Paper: 1-35.

Dell'Ariccia, M.G., M.R. Marquez and M.L. Laeven, 2010. Monetary policy, leverage, and bank risk-taking (No. 10-276). International Monetary Fund.

Federico, P., C. Vegh and G. Vuletin, 2014. Reserve requirement policy over the business cycle. NBER Working Papers, No. (w20612).

FSB/IMF/BIS, 2009. Guidance to assess the systemic importance of financial institutions, markets and instruments: Initial considerations: Report to the g-20 finance ministers and central bank governors. Prepared by the Staff of the International Monetary Fund and the Bank for International Settlements, and the Secretariat of the Financial Stability Board.

Gerlach, S., A. Giovannini, C. Tille and J. Viñals, 2009. Are the golden years of central banking over. The crisis and the challenges. Geneva Reports on the World Economy.

Gersl, A. and J. Seidler, 2012. Excessive credit growth and countercyclical capital buffers in basel III: An empirical evidence from central and East European countries. ACTA VSFS, 6(2): 91-107. View at Google Scholar

Goodhart, C., D. Tsomocos and A. Vardoulakis, 2009. Foreclosures, monetary policy and financial stability. Conference Proceedings of the 10th International, Academic Conference on Economic \& Social Development, Moscow.

Greene, W.H., 2007. Econometric analysis. 5th Edn.: McGraw-hill, Inc.

Igan, D.O. and H. Kang, 2011. Do loan-to-value and debt-to-income limits work? Evidence from Korea (No. 11/297). International Monetary Fund.

Illing, G., 2006. Financial stability and monetary policy-a framework. CESifo Working Paper Series, No. 1971.

Laker, J., 1999. Monitoring financial system stability. Reserve Bank of Australia Bulletin October 1999 Address by the Assistant Governor (Financial System), to the 52nd International Banking Summer School, Melbourne, 1 September 1999.

Obeid, R. and M. Adeinat, 2017. Determinants of net interest margin: An analytical study on the commercial banks operating in Jordan (2005-2015). International Journal of Economics and Financial Issues, 7(4): 515-525. View at Google Scholar

Schinasi, M., 2004. Defining Financial Stability (EPub) (No. 4-187). International Monetary Fund.

Tovar, M.C., M. Garcia-Escribano and M.M. Vera, 2012. Credit growth and the effectiveness of reserve requirements and other macroprudential instruments in Latin America. IMF Working Paper.

Valencia, F., 2014. Monetary policy, bank leverage, and financial stability. Journal of Economic Dynamics and Control, 47: 20-38. View at Google Scholar | View at Publisher 